\title{
TIPARP wt Allele
}

National Cancer Institute

\section{Source}

National Cancer Institute. TIPARP wt Allele. NCI Thesaurus. Code C118975.

Human TIPARP wild-type allele is located in the vicinity of 3q25.31 and is approximately $34 \mathrm{~kb}$ in length. This allele, which encodes TCDD-inducible poly [ADP-ribose] polymerase protein, plays a role in modifying guanine residues with ADP-ribose. 